\title{
Vertical distribution and daily movements of larval lobsters Homarus americanus over Browns Bank, Nova Scotia
}

\author{
Gareth C. Harding ${ }^{1}$, John D. Pringle ${ }^{1}$, W. Peter Vass ${ }^{1}$, Sifford Pearre Jr. ${ }^{2}$, \\ Stephen J. Smith ${ }^{1}$
}

${ }^{1}$ Fisheries and Oceans, Bedford Institute of Oceanography, PO Box 1006, Dartmouth, Nova Scotia B2Y 4A2, Canada

${ }^{2}$ Dalhousie University, Department of Oceanography, Halifax, Nova Scotia B3H 3M2, Canada

\begin{abstract}
The vertical migration of lobster larvae was suspected from previous neuston collections taken off southwest Nova Scotia, Canada. An electronically-controlled Tucker trawl was developed for discrete depth sampling and used to study the diel vertical distribution of lobster larvae, together with environmental variables, over Browns Bank in late August. Significant vertical migration is demonstrated for stage I lobster, which were most frequently caught between 15 and $30 \mathrm{~m}$ water depth during daylight but were rarely caught below $10 \mathrm{~m}$ at night. Stage I lobster generally stayed below light intensities of 100 to $200 \mu \mathrm{E} \mathrm{m}^{-2} \mathrm{~s}^{-1}$. Stage II and III lobster were collected throughout the upper 20 to $30 \mathrm{~m}$ of the ocean but were too rare to distinguish statistically between day and night depth-abundance patterns. Stages I, II and III lobster were all confined to the upper mixed layer, above the thermocline, which varied in depth with the tidal cycle. Stage IV lobster were caught almost entirely at the surface, with no significant difference between day and night abundances. These findings are novel and have important implications for the ecology and dispersal of larval Homarus americanus in offshore waters.
\end{abstract}

\section{INTRODUCTION}

A long-term objective of the Department of Fisheries and Oceans, Canada, is to determine whether many of the planktonic larvae produced by large offshore lobsters settle in the inshore grounds off southwest Nova Scotia and in the proximity of the Bay of Fundy (Pringle et al. 1983). Rogers et al. (1968), working off Rhode Island, found stage I lobster offshore in the Middle Atlantic Bight while fourth-stage larvae were most abundant closer to shore, which they suggested represented an onshore drift of larvae with time, consistent with the known surface circulation. Stasko (1978) proposed that larvae produced on Browns Bank would drift towards the Nova Scotian coast where they would settle and that an offshore migration of older lobster would complete this life cycle. Stasko \& Gordon (1983) subsequently undertook 2 seasonal surveys between Browns Bank and southwest Nova Scotia from which they found a prevalence of stage IV lobster in the neuston. Harding et al. (1983) attempted to explain this anomalous abundance of stage IV lobster by invoking larval drift from the northern face of Georges Bank. We undertook a preliminary neuston survey for lobster larvae between southwest Nova Scotia and Georges Bank in 1983. In these tows lobster were noticeably absent from daytime surface catches in the Gulf of Maine but appeared in the neuston shortly after dusk. However, all stages of lobster larvae were present at all times of the day over Georges Bank. Before the larger issue of inshore recruitment from offshore lobsters via larval drift can be addressed, it is necessary to accurately determine the vertical distribution of larvae in the field because current speed and direction vary with depth and position.

The vertical distribution of lobster larvae in the sea has been difficult to resolve because of both their patchy distribution (Raytheon 1979) and their relative scarcity in the plankton (Fogarty \& Lawton 1983). It is therefore a logistical and technical problem to adequately sample the larval lobster population in the water column. Our approach was to sample discrete depths in one location with as large a trawl as practical, day and night, for as long as possible until a temporal pattern emerged. Here, we present the results of an intensive $2 \mathrm{wk}$ field sampling program designed to 
distinguish the day and night depth preference of larval lobsters over Browns Bank.

\section{METHODS}

A Tucker trawl (see Clarke 1969) was redesigned to accept the electronic package used with our half-scale version of the BIONESS (Sameoto et al. 1979). The trawl is opened and closed at depth by electronically releasing horizontal, weighted bars which slide down lateral cables (Fig. 1). The trawl tripping electronics and release mechanism are similar in principle to BIONESS. An Applied Microsystems ${ }^{\mathrm{TM}}$ expanded CTD-12 is used to record water-flow inside and outside the net, net opening and closing events, pitch and roll of the net, depth, together with conductivity and temperature $1.5 \mathrm{~m}$ above the center of the net mouth. Information is sent up a conductor cable at $10 \mathrm{~s}$ intervals and received by a Commodore $4000 \mathrm{PET}^{\mathrm{TM}}$, with basic 4.0 for storage (CBM 4040 dual drive floppy disk) or hard copy (Tractor Printer 4022). The effective trawl mouth opening at $1.5 \mathrm{~m} \mathrm{~s}^{-1}$ perpendicular to the towing path is $2.5 \mathrm{~m}$ wide $\times 1 \mathrm{~m}$ deep. The net material is $1.6 \mathrm{~mm}$ Nitex mesh, $5 \mathrm{~m}$ long, with a pore to mouth area ratio of greater than 3.0 (Smith et al. 1968). This ratio was sufficient to avoid clogging problems, as detected by the difference in readings of inside and outside flow meters. TSK ${ }^{\mathrm{TM}}$ flow meters, modified with magnetically actuated Hall effect sensors, are mounted in a protected encasement in the trawl mouth, beyond the effects of the trawl and bridles near the CTD (Fig. 1). Net bars are suspended from a release mechanism similar to the type described for BIONESS. The levers within the release mechanism drop through a slotted shaft which is incremented by a stepping motor. Power
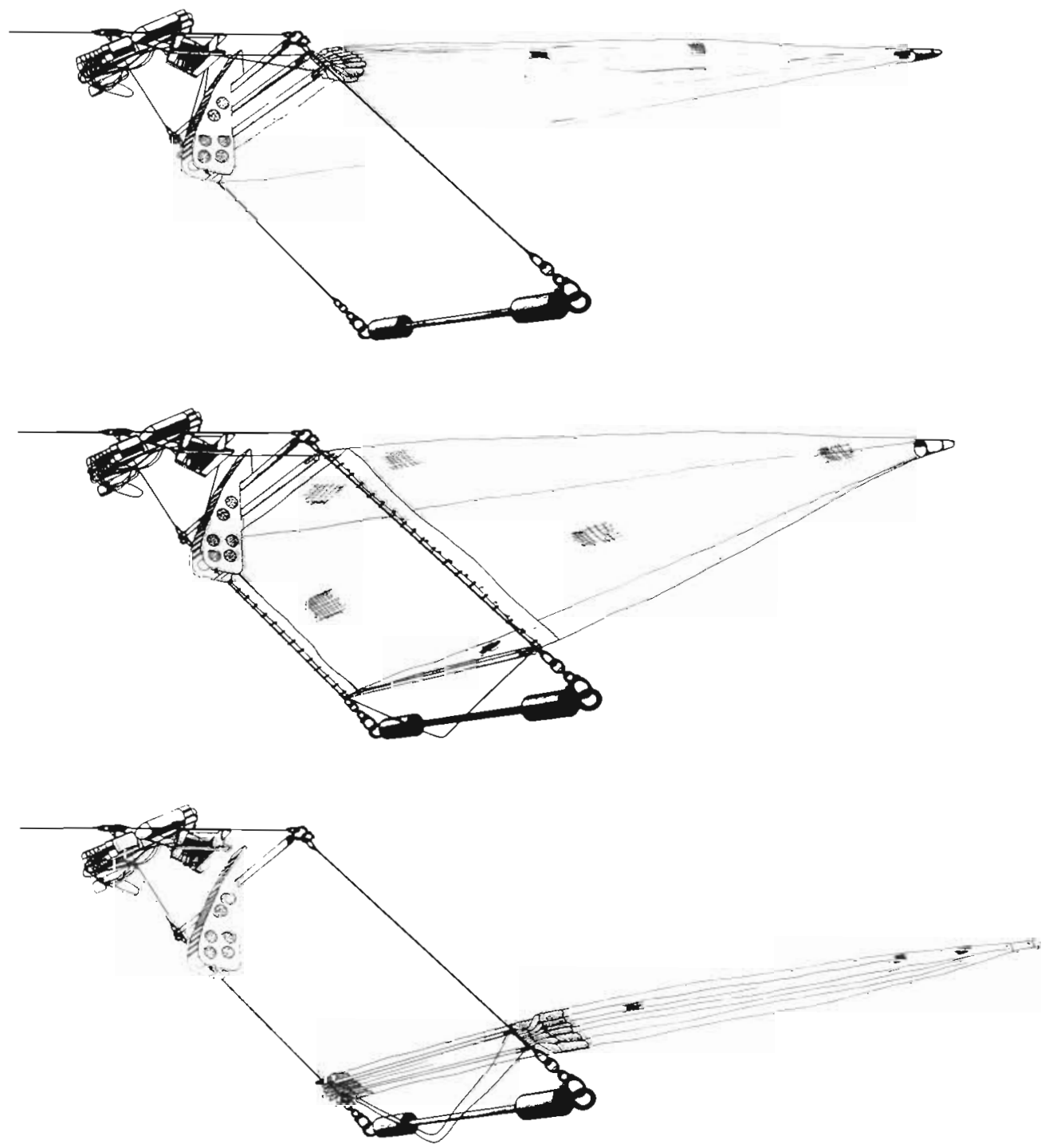

Fig. 1. Redesigned Tucker trawl for larval lobster work, showing deployment, opened, and closed positions (see text) 
to drive the stepping motor is supplied by a $20 \mathrm{~V}$ power supply on shipboard. A 6:1 gear reduction between the stepping motor and the slotted shaft is sufficient to allow rotation of the shaft while towing.

The trawl was deployed between 16 and 30 Aug 1984, to determine the extent and timing of daily migration of lobster larvae. We trawled within $3 \mathrm{~km}$ of $42^{\circ} 42^{\prime} \mathrm{N}, 66^{\circ} 10^{\prime} \mathrm{W}$, Browns Bank, with a bottom depth of $60 \pm 2 \mathrm{~m}$. Each tow was $30 \mathrm{~min}$ duration and tows were taken at $5 \mathrm{~m}$ intervals from the surface down to $30 \mathrm{~m}$ depth, thereafter infrequently at $10 \mathrm{~m}$ intervals to $50 \mathrm{~m}$. Approximately $6000 \mathrm{~m}^{3}$ of water was filtered per tow. Larval lobster abundances are reported as numbers per $5 \times 10^{3} \mathrm{~m}^{3}$, based on flow-meter readings. Eight daylight and 7 night depth series were completed with the Tucker trawl for a total of 112 tows. Light penetration was measured in the upper $20 \mathrm{~m}$ at $1200 \mathrm{~h}$ AST with a LICOR ${ }^{\mathrm{TM}}$ model LI-185B quantum meter and L1-192 SB underwater sensor. Incident radiation was recorded on deck throughout this study with LICOR $^{\text {TM }}$ LI-510 integrator, set for $10 \mathrm{~min}$ intervals.

\section{RESULTS}

A total of 347 stage I, 43 stage II, 15 stage III and 124 stage IV lobster larvae were caught. The mean ( \pm SE) day and night depth distributions are plotted for each larval stage, together with temperature, salinity and light intensity profiles (Fig. 2). Stage I larvae were present in $50 \%$ of our trawls. The day and night abundances of stage I lobster clearly had divergent depth patterns (Fig. 2). More larvae resided during daylight at the 15,20 and $30 \mathrm{~m}$ horizons, whereas at night stage I larvae had migrated into the surface waters with most of the larvae occurring at the surface, 5 and $10 \mathrm{~m}$ horizons (Fig. 2). On average, $<1 \%$ of the stage I lobster, integrated throughout the water column, occurred above $2.5 \mathrm{~m}$ depth during daylight, compared to $\sim 28 \%$ after dark (Fig. 2). Comparison of mean larval abundance and variance for each of the depth horizons by day and night showed the variance to be proportional to the mean. The large number of zeroes precluded the use of a logarithmic transform to

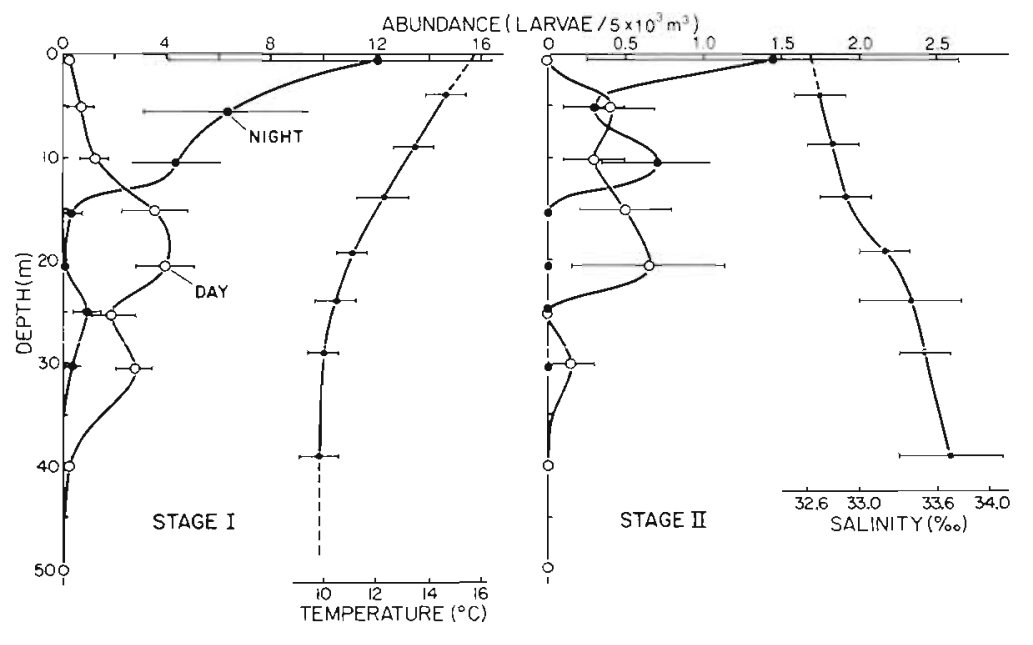

Fig. 2. Day and night-time vertical distributions of the 4 larval lobster stages $(\overline{\mathrm{x}} \pm \mathrm{SE}$ larvae $/ 5 \times$ $10^{3} \mathrm{~m}^{3}$ ) found over Browns Bank, Aug 1984. Shown are average temperature, salinity (95\% CI) and $1200 \mathrm{~h} \mathrm{AST} \mathrm{light} \mathrm{profiles}$

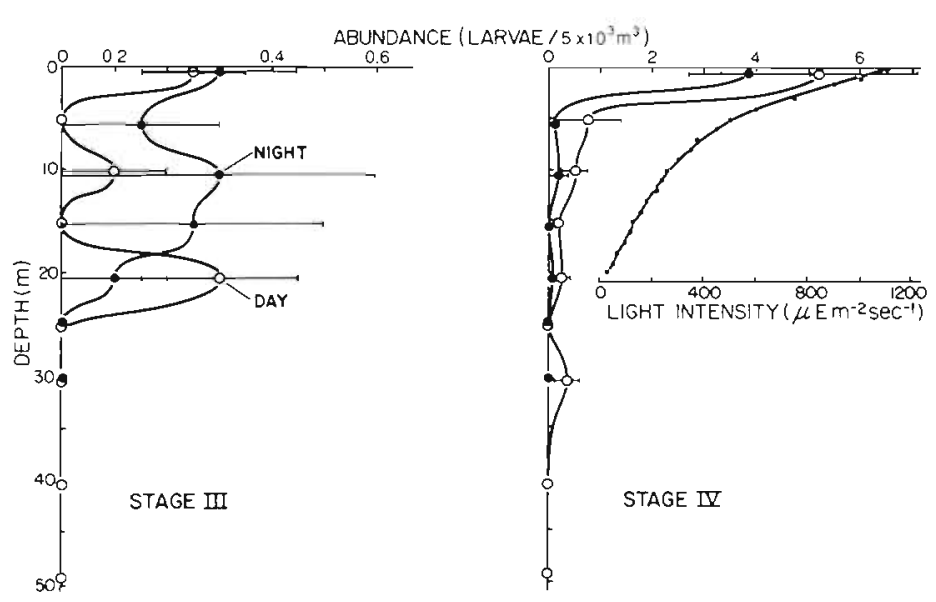


stabilize the variances. Therefore differences between mean abundances at depth by day and night were tested using a log-linear model assuming a Poisson distribution for the abundances and the variance proportional to the mean. While standard use of the Poisson distribution assumes that the variance is equal to the mean, incorporation of the proportional relationship into the estimation and testing will give valid results (McCullagh \& Nelder 1983).

Two potential outliers were identified for the stage I larvae. These were large catches made during the night, with one at the surface and the other at the $5 \mathrm{~m}$ horizon. These tow results were removed from the analysis. Tows from the $30 \mathrm{~m}$ and $40 \mathrm{~m}$ depth horizons were also deleted because there were only one and no positive tows, respectively, made during the night at these depths. The analysis of deviance of the log-linear model for the remaining stage I larvae data is presented in Table 1. Neither depth nor time (day/night) account for a significant proportion of the deviance. This indicates that we were sampling the entire depth range of stage I lobster and did not systematically overor undersample the population. However, time nested within depth (designated as DEPTH.TIME in Table 1) is significant. The associated parameter estimates and their standard errors indicate that abundances at the surface, $5 \mathrm{~m}$ and $10 \mathrm{~m}$ horizons during the day are significantly less than that of the surface horizon during the night. The abundances during the day at the deeper horizons (>15 m) were not significantly different. Parameter estimates for the night show that abundances from the surface to $25 \mathrm{~m}$ were similar with the exception of $20 \mathrm{~m}$ where abundance was significantly less. The mean fitted values for the model are given at the bottom of Table 1 . Note that inclusion of the 2 outliers identified earlier would not change the results in that night-time abundances are higher than daytime for the surface to $10 \mathrm{~m}$ depth horizons. The scale parameter for the final model of $1+$ DEPTH.TIME was estimated to be greater than one (2.877) justifying our decision to incorporate it in the analysis.

Similar analyses for stage II and III larvae indicated no significant relation between abundance and depth, time or time nested within depth. Stages II and III were included in Fig. 2 to indicate that they were caught over a broad depth range above the thermocline, contrary to previous studies. Stage II larvae were caught in $16 \%$ of the trawls and occurred mainly in the upper $20 \mathrm{~m}$. Stage III were present down to $20 \mathrm{~m}$ depth (Fig. 2).

Stage IV larvae were present in $75 \%$ of the surface trawls, representing $90 \%$ of the total catch. Stage IV were occasionally captured down to depths of $30 \mathrm{~m}$ (Fig. 2). Stage IV larval abundances appeared to be

Table 1. Analysis of deviance for stage I larvae assuming a log-linear model

\begin{tabular}{|c|c|c|c|c|}
\hline Model & $\begin{array}{c}\text { First difference } \\
\text { in deviance }\end{array}$ & $\begin{array}{l}\text { Degrees of } \\
\text { freedom }\end{array}$ & $\begin{array}{c}\mathrm{p} \text {-level } \\
\left(\chi^{2} \text {-test }\right)\end{array}$ & $\begin{array}{c}\text { Scale } \\
\text { parameter }\end{array}$ \\
\hline \multicolumn{5}{|l|}{1} \\
\hline + DEPTH & 10.20 & 5 & 0.779 & 4.080 \\
\hline+ TIME & 5.23 & 1 & 0.257 & 4.066 \\
\hline + TIME & 6.00 & 1 & 0.217 & 3.944 \\
\hline + DEPTH & 9.35 & 5 & 0.808 & 4.066 \\
\hline + DEPTH.TIME & 130.90 & 11 & 0.000 & 2.877 \\
\hline \multicolumn{5}{|c|}{ Parameter estimates (standard errors) for model: 1 + DEPTH.TIME } \\
\hline Depth $(\mathrm{m})$ & Day & Night & & \\
\hline Surface & $-2.787(0.930)$ & 0 & & \\
\hline 5 & $-2.068(0.790)$ & $-0.281(0.505)$ & & \\
\hline 10 & $-1.260(0.607)$ & $-0.002(0.452)$ & & \\
\hline 15 & $-0.179(0.445)$ & $-2.856(1.721)$ & & \\
\hline 20 & $-0.233(0.440)$ & $-3.010(1.412)$ & & \\
\hline 25 & $-0.851(0.574)$ & $-1.576(1.084)$ & & \\
\hline \multicolumn{5}{|c|}{ Fitted mean values (no. per $5000 \mathrm{~m}^{3}$ ) for model: $1+$ DEPTH.TIME } \\
\hline Depth $(\mathrm{m})$ & Day & Night & & \\
\hline Surface & 0.268 & 4.35 & & \\
\hline 5 & 0.550 & 3.283 & & \\
\hline 10 & 1.233 & 4.343 & & \\
\hline 15 & 3.639 & 0.250 & & \\
\hline 20 & 3.445 & 0.214 & & \\
\hline 25 & 1.857 & 0.900 & & \\
\hline
\end{tabular}


Table 2. Analysis of deviance for stage IV larvae assuming a log-linear model

\begin{tabular}{|c|c|c|c|c|}
\hline Model & $\begin{array}{c}\text { First difference } \\
\text { in deviance }\end{array}$ & $\begin{array}{l}\text { Degrees of } \\
\text { freedom }\end{array}$ & $\begin{array}{l}p \text {-level } \\
\left(\chi^{2} \text {-test }\right)\end{array}$ & $\begin{array}{c}\text { Scale } \\
\text { parameter }\end{array}$ \\
\hline \multicolumn{5}{|l|}{1} \\
\hline+ DEPTH & 225.80 & 4 & 0.0000 & 2.002 \\
\hline+ TIME & 3.41 & 1 & 0.1898 & 1.984 \\
\hline+ TIME & 8.10 & 1 & 0.1884 & 4.682 \\
\hline + DEPTH & 221.1 & 4 & 0.0000 & 1.984 \\
\hline + DEPTH.TIME & 6.30 & 5 & 0.6924 & 2.055 \\
\hline \multicolumn{5}{|c|}{ Parameter estimates (standard error) and fitted values for model: $1+$ DEPTH } \\
\hline Depth $(\mathrm{m})$ & Estimate & Mean fitted val & & \\
\hline Surface & 0 & 5.687 & & \\
\hline 5 & $-2.463(0.523)$ & 0.484 & & \\
\hline 10 & $-2.834(0.625)$ & 0.334 & & \\
\hline 15 & $-3.834(1.103)$ & 0.123 & & \\
\hline 20 & $-3.541(0.847)$ & 0.165 & & \\
\hline
\end{tabular}

related to depth only (Table 2 ). The parameter estimates for the model $1+\mathrm{DEPTH}$ and associated mean fitted values show that abundances at the surface horizon were significantly higher than the deeper horizons with abundances during daylight and night being similar. No outliers were identified for these data and analysis was confined to the first 5 depth horizons because no stage IV larvae were caught at $25 \mathrm{~m}$.

The model discussed above for stage I larvae provides estimates of mean abundance for depth by night and day. An alternate model was fitted to the stage I

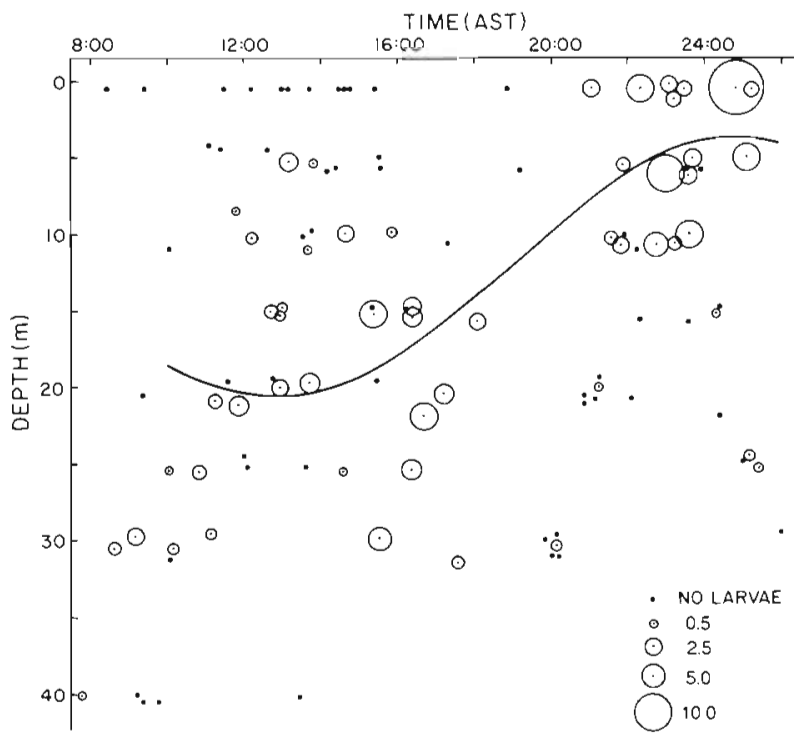

Fig. 3. Cumulative diagram of stage I lobster abundances, (no per $5000 \mathrm{~m}^{3}$ ), recorded from 16 to $30 \mathrm{Aug}$, presented on $24 \mathrm{~h}$ time (t) and depth (d) axes. Fitted sine curve: $d=12.27-8.29$ $\cos \omega \mathrm{t}-1.89 \sin \omega \mathrm{t}$, where $\omega=2 \pi / 24$ and $\mathrm{r}^{2}=0.55, \mathrm{~F}=31.5$,

$$
\mathrm{p}<0.001
$$

data to predict depths at which larvae would be most abundant at any particular time. The response variable for this model was depth weighted by abundance (no. per $5000 \mathrm{~m}^{3}$ ) and was regressed against time. A plot of stage I abundances recorded from 16 to $30 \mathrm{Aug}$ is presented on a depth and $24 \mathrm{~h}$ time axis in Fig. 3 . The size of the circles around each point reflect the size of the weight for each depth-time point. The best fit ( $p<0.001$ ) was given by a sine curve and this model is given on Fig. 3. The residuals from this model did not indicate any problems with the assumption of normality in this case.

The same analysis on a continuous time basis (16 to $30 \mathrm{Aug}$ ) gives an almost identical equation. The sinecurve function describes a population centered around $\sim 20 \mathrm{~m}$ at noon but rising to $4 \mathrm{~m}$ by midnight (Fig. 3). The phase of the sine curve is not significantly different from the solar cycle. On average stage I larvae stayed below a light intensity of $140 \mu \mathrm{E} \mathrm{m}^{-2} \mathrm{~s}^{-1}$ at $1200 \mathrm{~h} \mathrm{AST}$. The lower limit of stage I larvae coincided with the average halocline and thermocline depths of 20 to $30 \mathrm{~m}$, though there was a single larva caught at $40 \mathrm{~m}$ depth. This individual may represent a recent release rising towards the surface (Fig. 2). The structure and slope of the thermocline sometimes changed dramatically with the tidal cycle. Warmer water at depth, however, does not explain the presence of stage I larvae at $30 \mathrm{~m}$ depth. These larvae were caught in 8.5 to $11^{\circ} \mathrm{C}$ water, as indicated by the average thermal profile (Fig. 2).

Lobster larvae on Browns Bank in mid to late August were therefore largely confined to the warmer, uppermixed layer. Stage I larvae performed a typical nocturnal migration into the upper $10 \mathrm{~m}$ from daytime depths of 15 to $30 \mathrm{~m}$. Stage IV lobster were restricted mainly to the upper metre at all times of the day. 


\section{DISCUSSION}

The earliest observations on record of lobster larvae in the wild were made by Smith (1873) in mid-summer from Vineyard Sound and Buzzards Bay, off Massachusetts, USA. Smith frequently collected stage I and stage IV larvae at the surface during the day in dip and plankton nets. The literature since then on the depth distribution of lobster larvae is both diverse and fragmentary. The details of earlier studies are therefore collated, more or less chronologically, in Table 3 to facilitate a reappraisal of the vertical distribution and movements of lobster larvae in the wild.

\section{Inshore studies}

There have been numerous distributional studies of larval lobsters in inshore regions yet extensive vertical migrations, such as the daily $20 \mathrm{~m}$ migrations reported here in offshore waters, have not been observed. Most inshore investigators, however, were not looking for vertical migrations because they assumed that lobster larvae live continuously near the sea surface. This assumption was based on observations of aggregations of larvae near the surface when simultaneous surface and subsurface sampling was carried out (Table 3 ). This reasoning can be fallacious if the larval population is aggregated near the surface and either at some depth beneath the surface or diffusely spread throughout the subsurface waters.

The most detailed studies, to date, of the vertical distribution of lobster larvae in inshore waters have found that the early stages were present throughout the water column with aggregations at the surface in the southern Gulf of St. Lawrence (Scarratt 1973), in the upper $3 \mathrm{~m}$ (Collings et al. 1981) and at $3 \mathrm{~m}$ depth in the southern Gulf of Maine (Matthiessen \& Scherer 1983). The fourth and final planktonic stage is more restricted to near-surface waters (Templeman 1939, Bibb et al. 1983, Collings et al. 1983, Hudon et al. 1986), similar to our offshore results (Fig. 2).

There are conflicting accounts on whether lobster larvae undergo vertical migrations in inshore regions. Previous investigators have observed all larval stages of the lobster near the sea surface both day and night (Table 3). However, more larvae per tow were caught during daylight when the results of day and night sampling could be compared (Scarratt 1973, Bibb et al. 1983). Scarratt also found that early stage larval lobsters disappeared from the upper $1.2 \mathrm{~m}$ of the water column just after sunset and before sunrise, reminiscent of Smith's (1937) preliminary findings yet contrary to those of Hudon et al. (1986). During daylight, several investigators have observed increased surface catches of larvae under overcast skies, as opposed to sunny conditions, from simultaneous surface and subsurface plankton tows (Templeman \& Tibbo 1945, Harding et al. 1982, Hudon et al. 1986) and from seasonal surveys (Collings et al. 1983, Greenstein et al. 1983). There are reports also of lobster larvae progressively descending beneath the surface layer as dusk proceeds to night (Templeman \& Tibbo 1945, Lux et al. 1983). Harding et al. (1979) observed that lobster larvae disappeared completely from the sea surface at night under rainy skies during a seasonal neuston survey done after dark. Conversely, Templeman (1939) found, using paired surface and subsurface plankton tows, that moonlight attracted lobster larvae to the surface.

Most of the inshore observations can be explained by the light hypothesis proposed by Templeman and Tibbo (1945) which states that a minimum light intensity is required to attract Iarvae near the sea surface but above some intensity larvae seek lower light levels. This also agrees with the earlier laboratory findings of Hadley (1908) on the light response of stage I larvae older than $2 \mathrm{~d}$, stage II and III lobster; except for a few hours before each moult. This hypothesis does not, however, explain the observed difference between the small-scale vertical movements observed inshore and the $20 \mathrm{~m}$ migrations observed offshore. Summer light attenuation inshore in the Gulf of St. Lawrence (Harding et al. 1987) and offshore over Browns Bank (Fig. 2) are similar with $1 \%$ of surface radiation reaching 18 to $20 \mathrm{~m}$ depth. Other factors than light intensity and penetration, such as prey or predator interactions, may be responsible for the observed differences in the scale of vertical distribution and movements for inshore and offshore populations.

\section{Offshore studies}

Little was previously known about the depth distribution of lobster larvae in deep water over the continental shelf. Stasko (1977) reported that 12 stage I, 12 stage II, 28 stage III and 90 stage IV lobster were collected from 76 stations on the Scotian Shelf at which both surface and deep oblique tows were taken (Table 3). Only 1 stage I and 2 stage IV lobster were captured in gear towed beneath the surface $(1 \mathrm{~m})$ and these could have been captured as the nets passed through the surface water open (J. Reid pers. comm.). Stasko \& Gordon (1983) followed this study with a 2 yr, seasonal survey for lobster larvae using a variety of gear types in the most promising continental waters, specifically the Browns Bank region off southwest Nova Scotia (Table 3). They collected 3.5, 1.9 and 1.2 lobster larvae per tow at 0 to $0.2,0.2$ to 1.3 and 1 to $2 \mathrm{~m}$ depth, respectively (Table 3$)$. Only 12 larvae $(<0.1$ per 


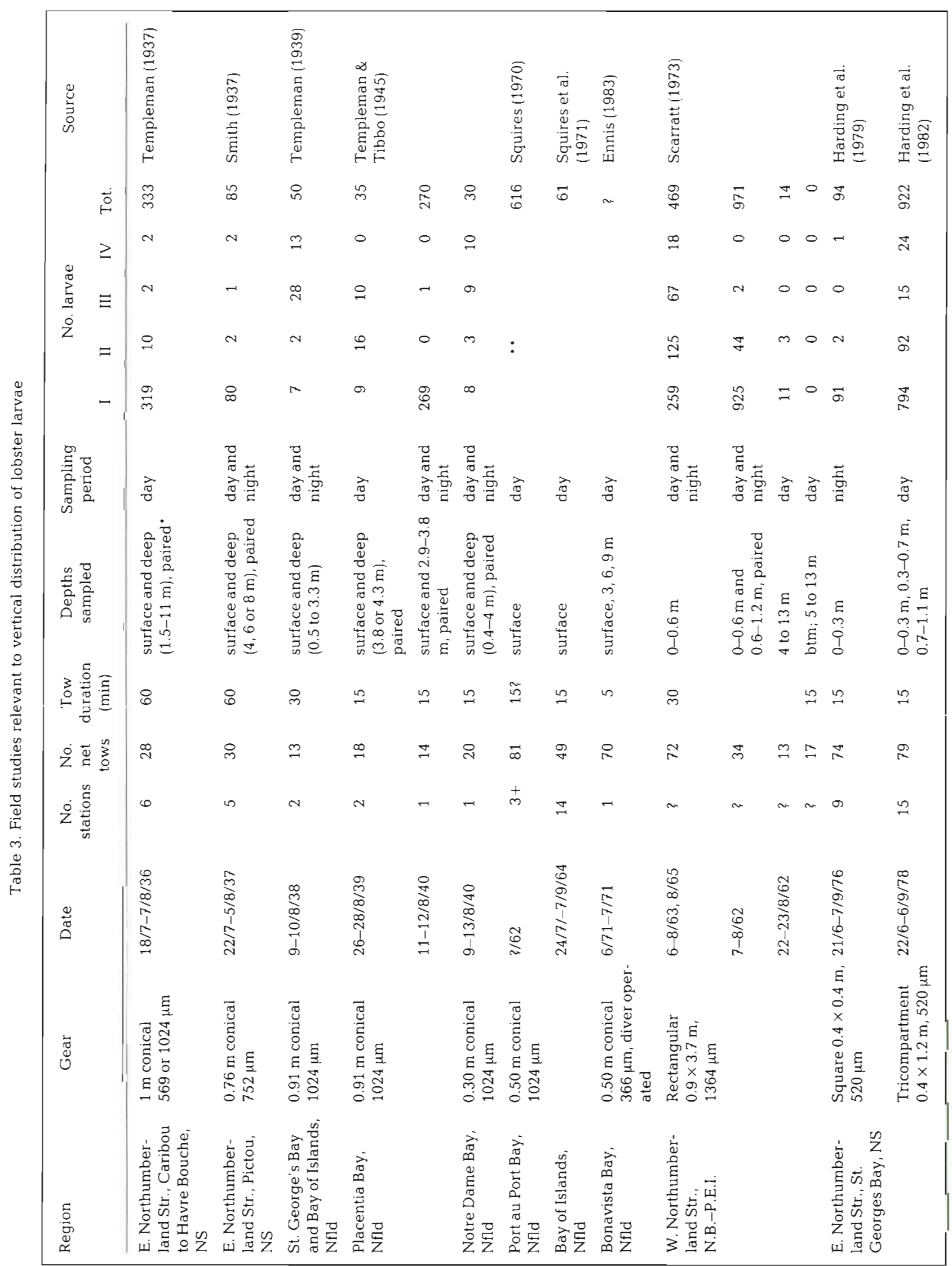


36

Mar Ecol. Prog. Ser. 41: 29-41, 1987

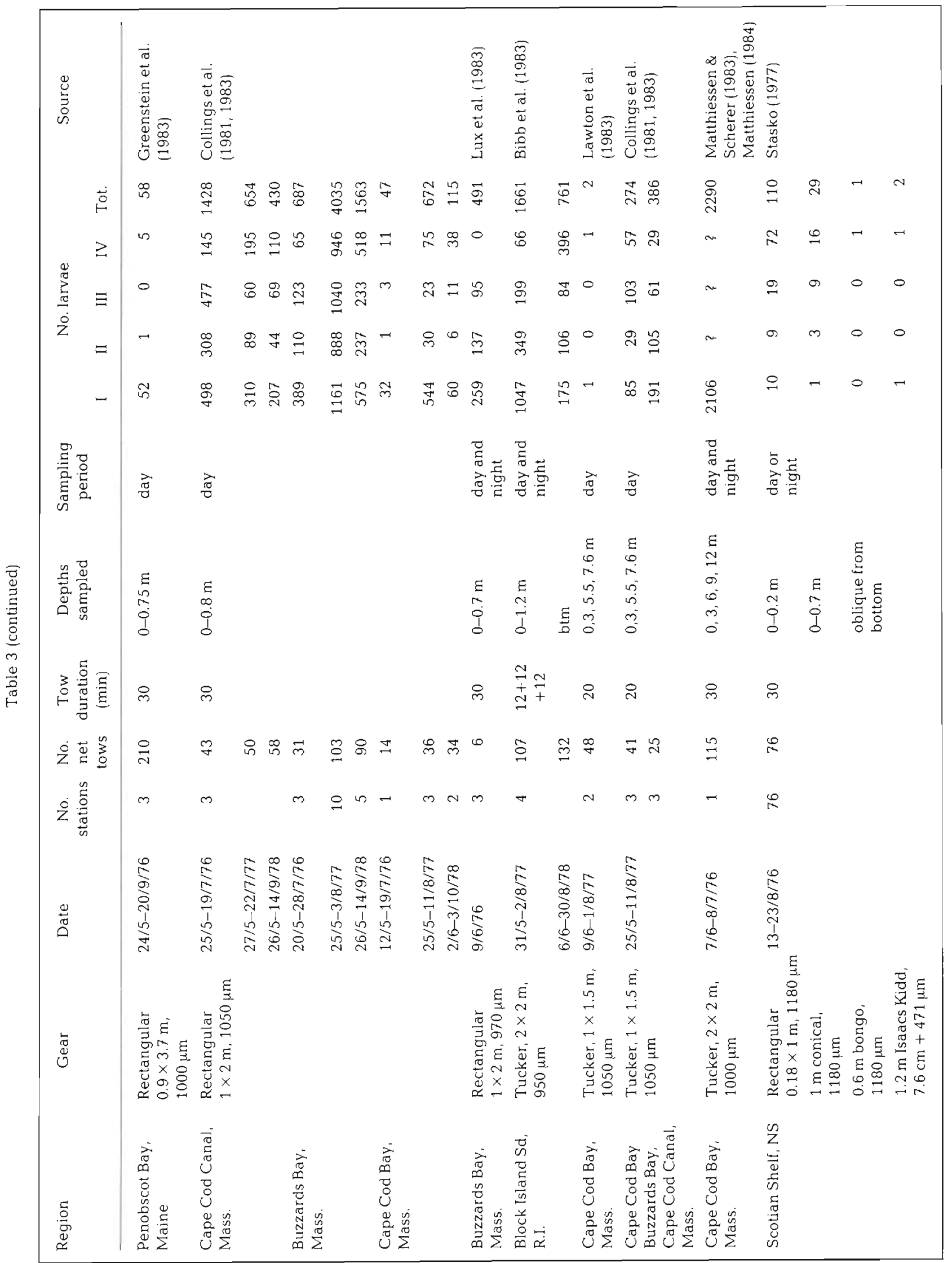




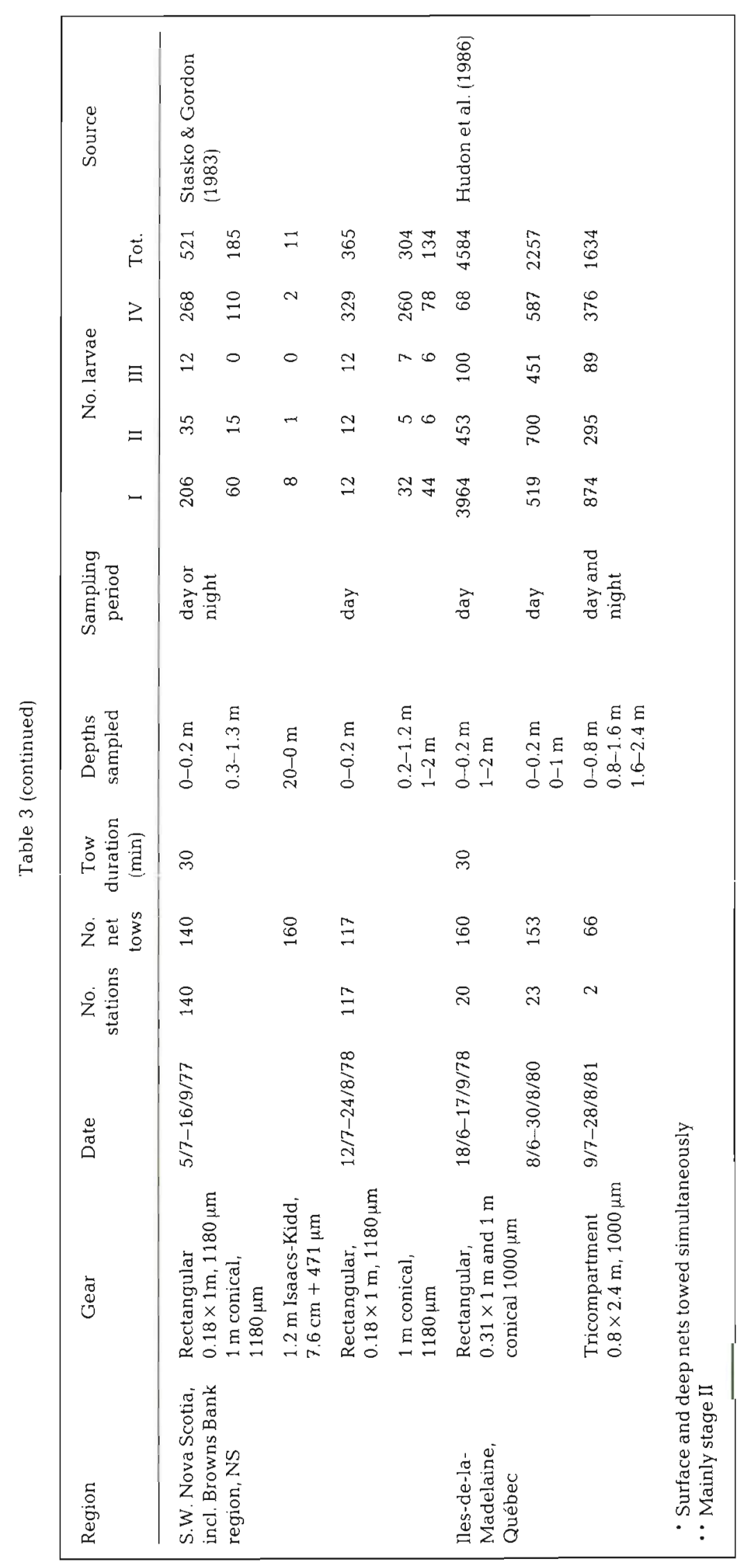


tow) were collected in 160 stepped oblique tows (20 to 10 to $2 \mathrm{~m}$ ) with an Isaacs-Kidd trawl; however, most lobster larvae would have passed through the $76 \mathrm{~mm}$ mesh of the main section of this net. Stage IV lobster larvae made up $66 \%$ of the total offshore catch (Stasko \& Gordon 1983) which is similar to the skewed distribution of developmental stages found off New England in coastal surface waters (Table 3). In 1977 when offshore sampling was done both day and night, $38 \%$ and $54 \%$ of the surface catch (0 to $1.2 \mathrm{~m}$ ) were stage I and IV, respectively, whereas $7 \%$ and $83 \%$ were stage I and IV the following year when all sampling was done during daylight. This discrepancy in the proportion of developmental stages between years can be explained readily by our findings of a migration of most of the stage I population into the surface waters at night combined with the persistence of fourth stage larvae in the surface waters (Fig. 2). Similarly, our results could also explain the greater proportion of stage IV larvae found in New England surface waters (Collings et al. 1981, 1983, Bibb et al. 1983, Fogarty et al. 1983, Grabe et al. 1983, Lawton et al. 1983, Lux et al. 1983, Matthiessen \& Scherer 1983) compared to that expected from estimates of natural mortality (Scarratt 1964, 1973, Harding et al. 1982). Another explanation is that larvae could be advected away from the 'spawning' sites so that the developmental stages are segregated from each other by drift and dilution. As we have seen, the preponderance of stage IV lobster in New England is such a widespread phenomena that this explanation is not considered tenable. It is more likely that the first 3 developmental stages of the lobster spend proportionately more time beneath the surface waters as we have found in offshore waters (Fig. 2).

\section{Laboratory studies and ecological implications}

The vertical extent of stage I lobster migration reported here, daily traversing as much as $30 \mathrm{~m}$ depth over Browns Bank, was not expected from the results of previous field studies. However, the early laboratory studies of Hadley $(1905,1908)$ hinted that this would be the case. Hadley noted that the larval response to the intensity and direction of light changed as the lobster developed. In the first hours after hatching, experimental larvae were most attracted to a light source of high intensity but this response reversed by the second day into a negative reaction to bright daylight, although stage I lobster were still positive to reduced light (Hadley 1908). These results anticipated not only a vertical migration cued to light intensity but the presence of some stage I larvae at the surface throughout the day. Hours before moulting into stage II, III or IV larval lobster were strongly attracted to bright light again (Had- ley 1908). This response could also explain the presence of some stage II and III larvae in the surface waters over Browns Bank during daylight. Lobster larvae had a negative response to daylight after moulting into the second and third developmental stages, and actively sought regions of reduced light (Hadley 1908). Stage II and III lobster larvae were too rare in our collections to statistically detect any day-night depth differences. Hadley (1908) found early stage IV larvae actively choose greater light intensities although this response reversed later in the larval stage. These results agree with our finding of $90 \%$ of the stage IV larvae being caught in the upper metre $(81 \%$ of surface tows were positive) over Browns Bank. Early experimental stage IV lobster were characterized also by continuous swimming near the surface which was more active and superficial in the presence of food (Hadley 1908). Unfortunately light intensity was never quantified in these behavioural studies of Hadley.

Later experimental studies indicated that the depth regulating activities of the first 3 larval stages were most responsive to pressure changes but that the presence of overhead light substantially reduced the reaction time at low pressures (Ennis 1975). As Hadley had found, early stage I lobster reacted more positively to overhead light intensities than $3 \mathrm{~d}$ old stage I, 6 to $8 \mathrm{~d}$ old stage II and $15 \mathrm{~d}$ old stage III larvae (Ennis 1975). However, the responses of larval lobsters, over a range of light intensities, were not consistent in this experimental design.

Templeman (1936) found that salinities as low as $21 \%$ were only slightly less favourable to lobster larvae than seawater for their survival to stage IV. Scarratt \& Raine (1967) showed that early stage I lobster avoided an experimental surface layer of $21.4 \%$ but not $26.7 \%$ salinity. Obviously salinity is of little importance in the ecology of lobster larvae except in the immediate vicinity of freshwater runoff, where larvae would be expected to select deeper more saline waters.

Templeman (1936) demonstrated that lobster larvae could be reared in the laboratory through the fifth stage at 10 to $20^{\circ} \mathrm{C}$ in the ample presence of prey over approximately 109 to $29 \mathrm{~d}$, respectively. MacKenzie (1985) found that over a range of 10 to $22^{\circ} \mathrm{C}$ there was no effect on larval survival in the laboratory up to the end of the second developmental stage, however, larvae reared at $10^{\circ} \mathrm{C}$ suffered significantly higher mortality $(>90 \%)$ before reaching the fifth or settled stage. It would appear that there is a considerable advantage to the species for individuals, at least stage III and IV larvae, to maintain themselves above the thermocline. In our Browns Bank study only one stage I larvae was caught below the $\sim 10^{\circ} \mathrm{C}$ thermocline at $30 \mathrm{~m}$ depth and most larvae were collected above the $20 \mathrm{~m}$ halocline (Fig. 2). 
The upper mixed layer over Browns Bank contains a species assemblage and size composition of prey previously found suitable for the larval lobster (Harding et al. 1983). We have not yet investigated this possibility in our Browns Bank study but it is almost certain that the vertical migrations of zooplankters, such as lobster larvae, are influenced by the changing depth distributions of their predators and prey as shown in other regions (Janssen \& Bradt 1980, Ohman et al. 1983, Harding et al. 1986).

Templeman (1936) has shown that a reduction in prey abundance from that considered optimal can effect both the duration of the larval stages and their survival. Reduction of prey levels to half optimal concentrations almost doubles the time needed to reach stage III (Templeman 1936). Hunger was found to postpone the final development of a strong negative response to light in late stage IV larvae whereas continual satiation favoured earlier settlement in laboratory conditions (Hadley 1908).

The advantages and disadvantages of a feeding planktonic larval phase, such as that evolved in many marine benthic macrofauna, has aroused scientific interest over the decades (Thorson 1950, Mileikovsky 1971, Sastry 1983, Olive 1985). The evolution of a planktotrophic larva offers more numerous progeny, though necessarily smaller because of the finite energy cost that can be allocated to reproduction (Vance 1973), with higher mortality than direct development of large eggs to juveniles in protective brood pouches. The lobster has evolved an intenmediate course with the mother carrying and protecting yolky eggs over the winter, which then hatch in the spring into carnivorous plankters of 4 to $6 \mathrm{wk}$ duration. The release of planktonic larvae serves to remove benthic organisms from the bottom at a critical size and stage in their development. It has been judged from both the lack of species and the predictable gaps present at certain sizes in the biomass spectrum of the benthos that the bottom is least favourable for survival due to either phylogenetic limitations inherent in meio- and macrofauna (Warwick 1984) or to physical constraints of grain size in the environment (Schwinghamer 1981). A bottom dwelling existence compresses a species habitat very nearly into 2 dimensions such that if the organisms are of a size which is too large to live interstitially but too small to effectively burrow into the sediments, they would be restricted to the surface and therefore be extremely vulnerable to predators. Schwinghamer (1985) believes that the usually low biomass of benthic organisms around the $1 \mathrm{~mm}$ ESD size category, which corresponds to the planktonic phase of most benthic organisms, is evidence for strong negative selection forces.

It is widely believed, however, that a planktonic existence in surface waters also makes larger organ- isms more vulnerable, but to visual predators during daylight (Hrbáček 1958, Brooks \& Dodson 1965, Iwasa 1982). The chances of a larval lobster surviving to the bottom-living stage are believed to be reduced by prolonging this phase of the life cycle (Templeman 1936, Harding et al. 1983). It is perhaps not fortuitous that larval lobsters are hatched to coincide with the warmest season (Harding et al. 1983) which would enhance growth and hasten settlement (Templeman 1936, Mackenzie 1985). One of the recognized benefits of a planktonic phase is that it serves to spread relatively immobile benthic species which are often habitat specific (Strathmann 1974, Ayal and Safriel 1982) and increases genetic exchange over longer geographic distances (Scheltema 1971, Underwood 1974, Crisp 1976). Adult lobsters are known to travel long distances on the bottom (Fogarty et al. 1980, Campbell \& Stasko 1985) and some portion of the offshore population is known to migrate seasonally onto banks (Uzmann et al. 1977, Pezzack \& Duggan 1986) which makes a planktonic stage less essential for dispersion. More importantly a planktonic existence brings the lobster into the photosynthetic zone of the ocean at a time when the surface water is warmest and small-copepod prey production is highest (Dagg \& Turner 1982, Davis 1984) which would result in rapid growth through a vulnerable size in its life history. A widely evolved compromise, considering the opposing forces of natural selection operating on a large planktonic predator, is for vertical migration to occur to take advantage of the prey and fast growth supported in the warm sunlit waters yet descend during daylight to avoid visual predators (Gliwicz 1986).

Acknowledgements. It is a pleasure to thank John Krebs, Kathy Patrick, Eric Wilson and Uma Earanky for analysing the trawl samples in the laboratory and Bob Semple for assistance in the field. We thank Miroslaw Jonasz and Keith Thompson. for their advice. The willing and able assistance of Captain Neil Barnes and the crew of the R. V. Lady Hammond made the field operations go smoothly. We particularly thank the anonymous referee who introduced us to a more appropriate statistical technique.

\section{LITERATURE CITED}

Ayal, Y., Safriel, U. N. (1982). r-Curves and the cost of the planktonic stage. Am. Nat. 119: 391-401

Bibb, B. G., Hersey, R. L., Marcello, R. A., Jr. (1983). Distribution and abundance of lobster larvae (Homarus americanus) in Block Island Sound. U. S. Dept. of Commerce, NOAA Tech. Rep. NMFS SSRF-775: 15-22

Brooks, J. L., Dodson, S. I. (1965). Predation, body size, and composition of plankton. Science 150: 28-35

Campbell, A., Stasko, A. B. (1985). Movements of tagged American lobsters, Homarus americanus, off southwestern Nova Scotia. Can. J. Fish. Aquat. Sci. 42: 229-238 
Clarke, M. R. (1969). A new midwater trawl for sampling discrete depth horizons. J. mar. biol. Ass. U. K. 49: 945-960

Collings, W. S., Cooper-Sheehan, C., Hughes, S. C., Buckley, J. L. (1981). Lobster larvae. In: The effects of power generation on some of the living marine resources of the Cape Cod Canal and approaches. Massachusetts Dept. Fish. Wildl. Recr. Vehicles. Div. Mar. Fish., Sandwich, Massachusetts, p. 21-97

Collings, W. S., Cooper-Sheehan, C., Hughes, S. C., Buckley, J. L. (1983). The spatio-temporal distribution of American lobster, Homarus americanus, larvae in the Cape Cod Canal and approaches. U. S. Dept. of Commerce, NOAA Tech. Rep. NMFS SSRF-775: 35-40

Crisp, D. J. (1976). The role of the pelagic larva. In: Davies, P. S. (ed.) Perspectives in experimental biology. I. Zoology. Pergamon Press, New York, p. 145-155

Dagg, M. J., Turner, J. T. (1982). The impact of copepod grazing on the phytoplankton of Georges Bank and the New York Bight. Can. J. Fish. Aquat. Sci. 39: 979-990

Davis, C. S. (1984). Predatory control of copepod seasonal cycles on Georges Bank. Mar. Biol. 82: 31-40

Ennis, G. P. (1975). Behavioral responses to changes in hydrostatic pressure and light during larval development of the lobster Homarus americanus. J. Fish. Res. Bd Can. 32: $271-281$

Ennis, G. P. (1983). The effect of wind direction on the abundance and distribution of decapod crustacean larvae in a Newfoundland nearshore area. Can. Tech. Rep. Fish. Aquat. Sci. 1138: 1-19

Fogarty, M. J., Borden, D. V. D., Russell, H. J. (1980). Movements of tagged American lobster, Homarus americanus, off Rhode Island. Fish. Bull. U. S. 78: 771-780

Fogarty, M. J., Hyman, M. A., Johnson, G. F., Griscom, C. A. (1983). Distribution, relative abundance, and seasonal production of American lobster, Homarus americanus, larvae in Block Island Sound in 1978. U. S. Dept. of Commerce, NOAA Tech. Rep. NMFS SSRF-775: 23-28

Fogarty, M. J., Lawton, R. (1983). An overview of larval American lobster, Homarus americanus, sampling programs in New England during 1974-79. U. S. Dept. of Commerce, NOAA Tech. Rep. NMFS SSRF-775: 9-14

Gliwicz, M. Z. (1986). Predation and the evolution of vertical migration in zooplankton. Nature, Lond. 320: 746-748

Grabe, S. A., Shipman, J. W., Bosworth, W. S. (1983). New Hampshire lobster larvae studies. U. S. Dept. of Commerce, NOAA Tech. Rep. NMFS SSRF-775: 53-57

Greenstein, D. M., Alexander, L. C., Richter, D. E. (1983). Abundance and distribution of lobster larvae (Homarus americanus) for selected locations in Penobscot Bay, Maine. U. S. Dept. of Commerce, NOAA Tech. Rep. NMFS SSRF-775: 59-61

Hadley, P. B. (1905). Phototropism in the larval and early adolescent stages of Homarus americanus. Science 22: $675-678$

Hadley, P. B. (1908). The behavior of the larval and adolescent stages of the American lobster (Homarus americanus). J. Comp. Neurol. Psychol. 18: 199-301

Harding, G. C., Drinkwater, K. F., Vass, W. P. (1983). Factors influencing the size of American lobster (Homarus americanus) stocks along the Atlantic coast of Nova Scotia Gulf of St. Lawrence, and Gulf of Maine: a new synthesis Can. J. Fish. Aquat. Sci 40: 168-184

Harding, G. C., Hargrave, B. T., Vass, W. P., Sheldon, R. W. Pearre, S., Jr. (1987). Vertical flux of particulate matter by sedimentation and zooplankton movements in St. Georges Bay, the southern Gulf of St. Lawrence. Biol. Oceanogr. 4: 323-357
Harding, G. C., Vass, W. P., Drinkwater, K. F. (1982). Aspects of larval lobster (Homarus americanus) ecology in $\mathrm{St}$. Georges Bay, Nova Scotia. Can. J. Fish. Aquat. Sci. 39: $1117-1129$

Harding, G. C., Vass, W. P., Hargrave, B. T., Pearre, S., Jr. (1986). Diel vertical movements and feeding activity of zooplankton in St. Georges Bay, N. S., using net tows and a newly developed passive trap. Can. J. Fish. Aquat. Sci. 43: 952-967

Harding, G. C., Wells, P. G., Drinkwater, K. F. (1979). The distribution and abundance of lobster larvae (Homarus americanus) in St. Georges Bay, Nova Scotia, in 1975 and 1976 and the possible effect that the Canso Causeway has had on the Chedabucto Bay lobster fishery. In: McCracken, F. D. (ed.) Canso marine environment workshop. Part 3 of 4 parts: Fishery impacts. Fish. Mar. Serv. Tech. Rep. 834: 101-107

Hrbáček, J. (1958). Typologie und Produktivität der teichartigen Gewässer. Verh. int. Verein. Limnol. 13: 394-399

Hudon, C., Fradette, P., Legendre, P. (1986). La répartition horizontale et verticale des larves de homard (Homarus americanus) autour des îles de la Madelaine, golfe du Saint-Lawrent. Can. J. Fish. Aquat. Sci. 43: 2164-2176

Iwasa, Y. (1982). Vertical migration of zooplankton: a game between predator and prey. Am. Nat. 120: 171-180

Janssen, J., Bradt, S. (1980). Feeding ecology and vertical migration of adult alewives (Alosa pseudoharengus) in Lake Michigan. Can. J. Fish. Aquat. Sci. 37: 177-184

Lawton, R., Kouloheras, E., Brady, P., Sides, W., Borgatti, M. (1983). Distribution and abundance of larval American lobsters, Homarus americanus Milne-Edwards in the western inshore region of Cape Cod Bay, Massachusetts. U. S. Dept. of Commerce, NOAA Tech. Rep. NMFS SSRF-775: $47-52$

Lux, F. E., Kelly, G. F., Wheeler, C. L. (1983), Distribution and abundance of larval lobsters (Homarus americanus) in Buzzards Bay, Massachusetts, during 1976-79. U. S. Dept. of Commerce, NOAA Tech. Rep. NMFS SSRF-775: 29-33

MacKenzie, B. R. (1985). Temperature considerations of larval lobster (Homarus americanus Milne Edwards) ecology in waters of southwestern Nova Scotia. M. Sc. thesis, Dalhousie Univ., Halifax

Matthiessen, G. C. (1984). The seasonal occurrence and distribution of larval lobsters in Cape Cod Bay. In: Davis, J. D., Merriman, D. (ed.) Lecture notes on coastal and estuarine studies. Vol. 11. Observations on the ecology and biology of western Cape Cod Bay, Massachusetts. Springer-Verlag, New York, p. 101-117

Matthiessen, G. C., Scherer, M. D. (1983). Observations on the seasonal occurrence, abundance, and distribution of larval lobsters (Homarus americanus) in Cape Cod Bay. U.S Dept. of Commerce, NOAA Tech. Rep. NMFS SSRF-775: $41-46$

McCullagh, P., Nelder, J. A. (1983). Generalized linear models. Chapman and Hall, New York

Mileikovsky, S. A. (1971). Types of larval development in marine bottom invertebrates, their distribution and ecological significance: a re-evaluation. Mar. Biol. 10: 193-213

Ohman, M. D., Frost, B. W., Cohen, E. B. (1983). Reverse diel vertical migration: an escape from invertebrate predators Science 220: 1404-1407

Olive, P. J. W. (1985). Covariability of reproductive traits in marine invertebrates: implications for the phylogeny of the lower invertebrates. In: Morris, S. C., George, J. D., Gibson, R., Platt, H. M. (ed.) The origins and relationships of lower invertebrates. Clarendon Press, Oxford, p. 42-59 
Pezzack, D. S., Duggan, D. R. (1986). Evidence of migration and homing of lobsters (Homarus americanus) on the Scotian Shelf. Can. J. Fish. Aquat. Sci. 43: 2206-2211

Pringle, J. D., Robinson, D. G., Ennis, G. P., Dube, P. (1983). An overview of the management of the lobster fishery in Atlantic Canada. Can. MS Rep. Fish. Aquat. Sci. 1701: 1-103

Raytheon Company (1979). Distribution and abundance of lobster larvae in Block Island Sound, 1978. New England Power Co., Westboro, Massachusetts

Rogers, B. A., Cobb, J. S., Marshall, N. (1968). Size comparisons of inshore and offshore larvae of the lobster Homarus americanus, off southern New England. Proc. natn. Shellfish. Ass. 58: 78-81

Sameoto, D. D., Jaroszynski, L. O., Fraser, W. B. (1979). Bedford Institute of Oceanography net and environmental sensing system (BIONESS) construction details. Fish. Mar. Serv. Tech. Rep. 903: 1-47

Sastry, A. N. (1983). Pelagic larval ecology and development. In: Vernberg, F. J., Vernberg, W. B. (ed.) The biology of Crustacea. Academic Press, New York, p. 213-282

Scarratt, D. J. (1964). Abundance and distribution of lobster larvae (Homarus americanus) in Northumberland Strait. J. Fish. Res. Bd Can. 21: 661-680

Scarratt, D. J. (1973). Abundance, survival, and vertical and diurnal distribution of lobster larvae in Northumberland Strait, 1962-63, and their relationships with commercial stocks. J. Fish. Res. Bd Can. 30: 1819-1824

Scarratt, D. J., Raine, G. E. (1967). Avoidance of low salinity by newly hatched lobster larvae. J. Fish. Res. Bd Can. 24: 1403-1406

Scheltema, R. S. (1971). Larval dispersal as a means of genetic exchange between geographically separated populations of shallow-water benthic marine gastropods. Biol. Bull. mar. biol. Lab., Woods Hole 140: 284-322

Schwinghamer, P. (1981). Characteristic size distributions of integral benthic communities. Can. J. Fish. Aquat. Sci. 38 $1255-1263$

Schwinghamer, P. (1985). Observations on size-structure and pelagic coupling of some shelf and abyssal benthic communities. In: Gibbs, P. E. (ed.) Proceedings 19th European Marine Biology Symposium. Cambridge Univ. Press, Cambridge, p. 347-360

Smith, G. F. M. (1937). Plankton tows for lobster larvae 1937. Biol. Bd Can. MS Rep. 193B: $1-4$

Smith, P. E., Counts, R. C., Clutter, R. I. (1968). Changes in filtering efficiency of plankton nets due to clogging under tow. J. Cons. perm. int. Explor. Mer 32: 232-248
Smith, S. I. (1873). The early stages of the American lobster (Homarus americanus Edwards). Trans. Conn. Acad. Arts Sci. 2: $351-381$

Squires, H. J. (1970). Lobster (Homarus americanus) fishery and ecology in Port au Port Bay, Newfoundland, 1960-65. Proc. natn. Shellfish. Ass. 60: 22-39

Squires, H. J., Tucker, G. E., Ennis, G. P. (1971). Lobster (Homarus americanus) in Bay of Islands, Newfoundland, 1963-65. Fish. Res. Bd Can. MS Rep. Ser. 1151: 1-58

Stasko, A. B. (1977). Lobster larvae on the Scotian Shelf. Can. Atl. Fish. Sci. Adv. Comm. Res. Doc. 77/31

Stasko, A. B. (1978). Inshore-offshore SW Nova Scotia lobster stock interaction: a hypothesis. Can. Atl. Fish. Sci. Adv. Comm. Res. Doc. 78/37

Stasko, A. B., Gordon, D. J. (1983). Distribution and relative abundance of lobster larvae off southwestern Nova Scotia 1977-1978. Can. Tech. Rep. Fish. Aquat. Sci. 1175: $1-23$

Strathmann, R. (1974). The spread of sibling larvae of sedentary marine invertebrates. Am. Nat. 108: 29-44

Templeman, W. (1936). The influence of temperature, salinity, light and food conditions on the survival and growth of the larvae of the lobster (Homarus americanus). J. biol. Bd Can. 2: 485-497

Templeman, W. (1937). Habits and distribution of larval lobsters (Homarus americanus). J. biol. Bd Can. 3: 343-347

Templeman, W. (1939). Investigations into the life history of the lobster (Homarus americanus) on the west coast of Newfoundland, 1938. Nfld. Dept. Nat. Resour. Res. Bull. (Fish.) 7: 33-52

Templeman, W., Tibbo, S. N. (1945). Lobster investigations in Newfoundland 1938 to 1941 . Nfld. Dept. Nat. Resour. Res. Bull. (Fish.) 16: 60-98

Thorson, G. (1950). Reproductive and larval ecology of marine bottom invertebrates. Biol. Rev. 25: 1-45

Underwood, A. J. (1974). On models for reproductive strategy in marine benthic invertebiates. Añi. Nât. 108: 874-878

Uzmann, J. R., Cooper, R. A., Pecci, K. J. (1977). Migration and dispersion of tagged American lobsters, Homarus americanus, on the southern New England continental shelf. U. S. Dept. of Commerce, NOAA Tech. Rep. NMFS SSRF-705: 1-92

Vance, R. R. (1973). On reproductive strategies in marine benthic invertebrates. Am. Nat. 107: 339-352

Warwick, R. M. (1984). Species size distributions in marine benthic communities. Oecologia (Berl.) 61: 32-41 